\title{
Climate-induced change in biogenic bromine emissions from the Antarctic marine biosphere
}

\author{
Claire Hughes, ${ }^{1,2}$ Martin Johnson, ${ }^{1}$ Roland von Glasow, ${ }^{1}$ Rosie Chance, ${ }^{1}$ Helen Atkinson, ${ }^{1,3}$ \\ Terri Souster, ${ }^{3}$ Gareth A. Lee, ${ }^{1}$ Andrew Clarke, ${ }^{1,3}$ Michael Meredith, ${ }^{3}$ Hugh J. Venables, ${ }^{3}$ \\ Suzanne M. Turner, ${ }^{1}$ Gill Malin, ${ }^{1}$ and Peter S. Liss ${ }^{1}$
}

Received 10 January 2012; revised 14 May 2012; accepted 10 June 2012; published 25 August 2012.

[1] Climate change and human activities are expected to have a major impact on the structure and functioning of marine ecosystems and the biogeochemical cycles they mediate in the coming years. Here we describe time series measurements of biogenic bromocarbons $\left(\mathrm{CHBr}_{3}\right.$ and $\left.\mathrm{CH}_{2} \mathrm{Br}_{2}\right)$ collected in coastal waters of the western Antarctic Peninsula which is one of the world's most rapidly changing marine environments. Our measurements spanned a period of changing sea-ice dynamics and phytoplankton community structure driven by climatic forcing. Specifically, the occurrence of high chlorophyll $a$ concentrations $\left(\geq 5 \mu \mathrm{g} \mathrm{L}^{-1}\right)$ and dominance of the largest phytoplankton size fraction $(\geq 20 \mu \mathrm{m})$ indicating diatom bloom conditions was reduced following winter periods with a relatively short winter sea-ice duration ( $<50$ days). While large inter-annual variability in seawater $\mathrm{CHBr}_{3}$ concentrations was observed alongside these changes the same was not found for $\mathrm{CH}_{2} \mathrm{Br}_{2}$ which is surprising given their proposed common source. Seawater $\mathrm{CHBr}_{3}$ concentrations were found to be significantly higher $\left(122[14.7-580] \mathrm{pmol} \mathrm{L}^{-1}, \mathrm{P}<0.0001\right.$, Mann-Whitney) in samples collected in diatom bloom compared to non-bloom waters (42.9 [12.0-126] pmol L $\left.{ }^{-1}\right)$. A comparison of sea-to-air flux rates suggests that a switch from diatom bloom to non-bloom conditions results in a factor of 3-4 decrease in average $\mathrm{CHBr}_{3}$ sea-to-air emission rates which will reduce the supply of biogenic bromine to the atmosphere. Our calculations suggest that this will drive a decrease in inorganic bromine levels in the troposphere by a factor of 2-3 outside of ozone depletion events with potentially important implications for ozone cycling and dimethyl sulphide oxidation. This work has captured and crucially quantified the impact of a climate-induced change in a marine ecosystem on ocean-atmosphere biogeochemistry.

Citation: Hughes, C., et al. (2012), Climate-induced change in biogenic bromine emissions from the Antarctic marine biosphere, Global Biogeochem. Cycles, 26, GB3019, doi:10.1029/2012GB004295.

\section{Introduction}

[2] It is important to identify couplings between the climate system and the biogeochemical processes that influence atmospheric composition and chemistry to allow us to predict how the Earth's system will operate in the future [Denman et al., 2007]. The structure and functioning of marine ecosystems are controlled by climatic conditions that set upper ocean temperatures, stratification, light levels and $\mathrm{pH}$ [Hoegh-Guldberg and Bruno, 2010]. In return the marine biosphere drives the oceanic production and uptake of a range of trace gases that contribute to atmospheric composition and

\footnotetext{
${ }^{1}$ Laboratory for Global Marine and Atmospheric Chemistry, School of Environmental Sciences, University of East Anglia, Norwich, UK.

${ }^{2}$ Now at Environment Department, University of York, York, UK.

${ }^{3}$ British Antarctic Survey, Cambridge, UK.

Corresponding author: C. Hughes, Environment Department, University of York, York Y010 5DD, UK. (c.hughes@york.ac.uk)

(C)2012. American Geophysical Union. All Rights Reserved. 0886-6236/12/2012GB004295
}

chemistry [Liss, 2007]. Such feedbacks have the potential to amplify or attenuate climate change but the complexity of biogeochemical cycles can make it difficult to quantify the magnitude of the linkages with climatic forcing. More observations of biogeochemical responses to climate change are needed [Gruber, 2011], especially in regions of rapid change and those where changes in marine ecosystems have already been observed to occur such as the western Antarctic Peninsula (WAP).

[3] The WAP is the most rapidly warming region in the Southern Hemisphere, with the observed increase in winter air temperatures being 5 times the global average over the past 50 years [Vaughan et al., 2003] and with a contemporaneous strong warming of the upper ocean [Meredith and King, 2005]. This climatic warming has resulted in a reduction in the duration of winter fast-ice [Stammerjohn et al., 2008]; combined with other climatic changes, including deeper mixing driven by higher wind speeds and increased cloudiness, this has led to significant changes in phytoplankton biomass and community composition [Montes-Hugo et al., 2009]. Sea-ice dynamics play a major role in controlling 
marine phytoplankton growth and community structure in the polar regions. Sea-ice can seed surface waters with bloom-forming diatoms and essential nutrients such as iron, and control phytoplankton community structure through its impact on water column stability [Garibotti et al., 2003]. The presence of seasonal sea-ice can enhance stratification in spring and summer through freshening of surface waters; it can also isolate the winter ocean from deep mixing due to wind stress. Changing conditions has resulted in a reduction in surface chlorophyll $a$ concentrations by an average of $12 \%$ on the WAP over the last 30 years. This includes the reduced occurrence of high biomass diatom blooms $\left(\geq 5 \mu \mathrm{g} \mathrm{L}^{-1}\right.$ chlorophyll $a$ ) in the northern sector of the peninsula and increases in chlorophyll $a$ to the south associated with a switch from perennial to seasonal sea-ice [Montes-Hugo et al., 2009]. The delineation of these different responses was found to be $63^{\circ} \mathrm{S}$ for the period (1998 to 2006) considered in the Montes-Hugo et al. [2009] study but as warming continues this is likely to move further south. Given that diatoms are major players in the cycling of important elements in surface waters the biogeochemical consequences of shifts in the phytoplankton community, such as those seen along the WAP [Montes-Hugo et al., 2009], are likely to be substantial.

[4] It is suggested that marine diatoms produce a wide range of trace gases that are emitted to the atmosphere and play roles in controlling atmospheric chemistry [Liss, 2007]. For example, studies suggest that diatoms are a source of bromocarbons such as bromoform $\left(\mathrm{CHBr}_{3}\right)$ and dibromomethane $\left(\mathrm{CH}_{2} \mathrm{Br}_{2}\right)$ in seawater (reviewed by Quack and Wallace [2003] and Moore et al. [1996]). Once across the sea surface both $\mathrm{CHBr}_{3}$ and $\mathrm{CH}_{2} \mathrm{Br}_{2}$ are broken down by photolysis and reactions with $\mathrm{OH} / \mathrm{Cl}$ and release inorganic bromine molecules. This inorganic bromine can then interact directly with ozone to form bromine monoxide $(\mathrm{BrO})$, reduce ozone formation by decreasing the levels of nitrogen oxides [von Glasow and Crutzen, 2007] and can reduce the cloud condensation nuclei-forming potential of dimethyl sulphide (DMS) [von Glasow and Crutzen, 2004]. The convective transport of biogenic bromocarbons such as $\mathrm{CHBr}_{3}$ to the tropical tropopause and resulting ozone-depletion has been suggested to represent a potential link between ocean biology, atmospheric chemistry and climate [Yang et al., 2005; Salawitch, 2006]. Previous studies have reported elevated bromocarbon concentrations in areas of high biological activity in polar regions [Reifenhäuser and Heumann, 1992] and shown that natural communities of polar diatoms are a strong source of $\mathrm{CHBr}_{3}$ and $\mathrm{CH}_{2} \mathrm{Br}_{2}$ [Sturges et al., 1992]. Thus climatic variability at high latitudes could impact the supply of biogenic bromine to the atmosphere through alterations in phytoplankton biomass and community composition.

[5] The focus of this work is the Rothera Time series (RaTS) site located in coastal waters of the western Antarctic Peninsula at $67^{\circ} \mathrm{S}$ (Figure 1). Our previous measurements at the RaTS site (2005-2007) [Hughes et al., 2009] revealed elevated seawater bromocarbon concentrations and high seato-air emission rates during the summer (October to April) diatom bloom. Here we compare these published results to data collected at the RaTS site more recently (2008-2010) during a period when sea-ice dynamics were altered and changes in the phytoplankton community consistent with the shifts observed recently in the northern sector of the peninsula [Montes-Hugo et al., 2009] were apparent. The aim of this study was to determine how climate-induced changes in the marine biosphere alter bromocarbon concentrations and emissions from seawater, and assess the relevance of this for the supply of inorganic bromine to the Antarctic marine boundary layer.

\section{Methodology}

\subsection{Study Site and Ancillary Parameters}

[6] Samples were collected at the RaTS site located in Ryder Bay at the northern end of Marguerite Bay (Figure 1), on the western coast of the Antarctic Peninsula. The RaTS site is located approximately $4 \mathrm{~km}$ offshore $\left(67^{\circ} 34.2^{\prime} \mathrm{S}\right.$, $\left.68^{\circ} 13.5^{\prime} \mathrm{W}\right)$ to the east of Adelaide Island and has a waterdepth of $520 \mathrm{~m}$. Since 1997 regular sampling has been done from the main RaTS depth $(15 \mathrm{~m})$ using a hand-winched Niskin bottle deployed from a small boat for size-fractionated chlorophyll $a$ concentrations [Clarke et al., 2008]. Water column profiles of Conductivity, Temperature and Depth are also collected using a SeaBird SBE19CTD probe. Mixedlayer depths are taken as the depth where the density difference relative to the surface is $0.05 \mathrm{~kg} \mathrm{~m}^{-3}$. The level of ice cover within Ryder Bay was assessed visually by the Rothera Marine Assistant using an ice-index (0-10). An ice-index of 10 indicates total ice-cover with fast ice, and 0 means open water. Intermediate scores indicate a combination of either incomplete fast-ice cover, or the presence of other forms of ice (mainly pack-ice or brash ice).

\subsection{Bromocarbon Sampling and Analysis}

[7] Bromocarbon sampling and analytical procedures for the periods February 2005 to April 2007 and October 2008 to March 2010 are described in detail in a previous publication [Hughes et al., 2009]. In brief, air samples (1 L) were drawn on to a sorbent tube using a glass syringe and the bromocarbons were extracted from $40 \mathrm{~mL}$ seawater samples collected from the surface and $15 \mathrm{~m}$ depth by purging using oxygen-free nitrogen (OFN). All samples were trapped on Markes sorbent tubes containing Tenax, Carbograph and Carboxen, desorbed using a Markes Unity thermal desorption unit and UltrA autosampler and were then analyzed using an Agilent 6890 gas chromatograph coupled to a 5973 mass spectrometer. As before, samples collected during the winter (April to October) were stored in Swagelok capped, sorbent tubes at $-20^{\circ} \mathrm{C}$ until analysis at the start of the following summer period. All samples collected during the summer months were analyzed within a few hours of collection. Calibrations were performed using liquid standards (97\% $\mathrm{CHBr}_{3}$ Lancaster Synthesis; 99\% $\mathrm{CH}_{2} \mathrm{Br}_{2}$, Acros Organics) gravimetrically prepared in HPLC grade methanol (Fisher). Analytical detection limits were $0.3 \mathrm{pmol} \mathrm{L}^{-1}$ (seawater) and 0.1 ppt (air) for both $\mathrm{CHBr}_{3}$ and $\mathrm{CH}_{2} \mathrm{Br}_{2}$. Average percent analytical error calculated from repeat standard additions was $<10 \%$ for both $\mathrm{CHBr}_{3}$ and $\mathrm{CH}_{2} \mathrm{Br}_{2}$.

\subsection{Gas Flux Calculations}

[8] Sea-to-air gas flux rates $\left(\mathrm{F}, \mathrm{nmol} \mathrm{m} \mathrm{m}^{-2} \mathrm{~d}^{-1}\right)$ were calculated using equation (1) [Liss and Slater, 1974], where $k$ 


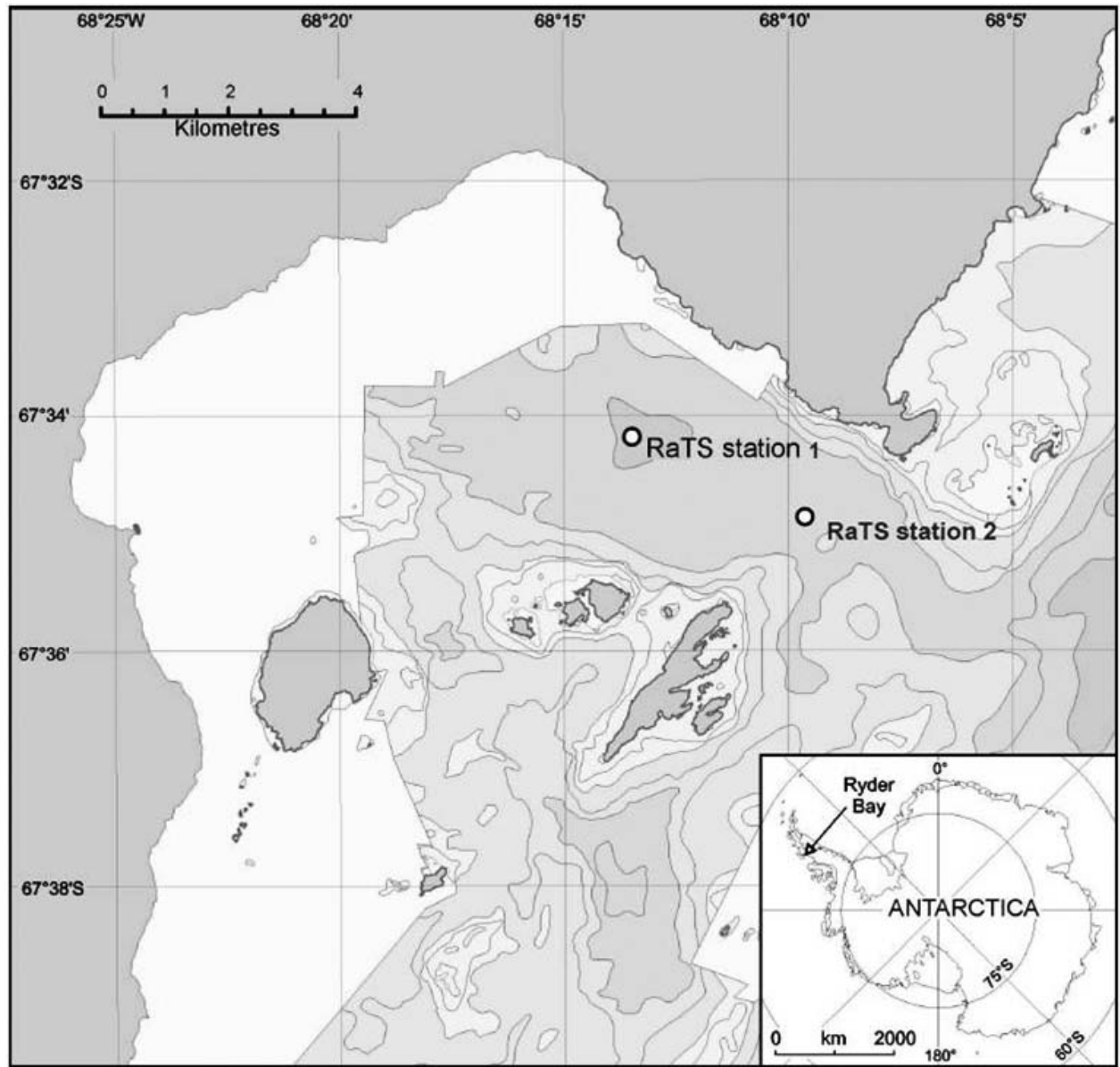

Figure 1. Map showing the location of the Rothera Time series (RaTS) site on the western Antarctic Peninsula. RaTS station 1 is the main time series site. Station 2 is visited if station 1 is not accessible due to ice or weather conditions. Surveys have shown that water column biophysical conditions at the two stations are comparable [Clarke et al., 2008].

is the gas transfer velocity and $\Delta \mathrm{C}$ is the disequilibrium between the air and liquid phases.

$$
\mathrm{F}=k \Delta \mathrm{C}
$$

The numerical scheme of Johnson [2010] was used to calculate $k$ accounting for both gas and liquid phase resistances to transfer. The parameterization of Nightingale et al. [2000] was used to calculate the liquid phase transfer velocity $\left(k_{w}\right)$ and the equations given in Duce et al. [1991] were employed to calculate the gas phase transfer velocity $\left(k_{a}\right)$. The Johnson [2010] scheme calculates temperature and salinity dependent Henry's Law constants and Schmidt numbers.

\subsection{Tropospheric Budget Calculations}

[9] To estimate the impact of sea-to-air bromocarbon emissions on the levels of inorganic bromine in the marine boundary layer we carried out budget calculations. We assume a situation where a flux, $\mathrm{F}\left(\mathrm{nmol} \mathrm{m}^{-2} \mathrm{~s}^{-1}\right)$, of organic bromine enters the atmosphere and is dispersed vertically in a layer of depth $\mathrm{z}(\mathrm{m})$ leading to an increase in the atmospheric concentration of organic bromine, $c_{\mathrm{O}}$ (in $\mathrm{mol} \mathrm{m}^{-3}$ ). In the atmosphere the organic bromine is subject to photochemical loss (breakdown by radicals such as $\mathrm{OH}$ and photolysis) with first order loss rate, $\mathrm{k}_{\mathrm{O}}\left(\mathrm{s}^{-1}\right)$, and dry deposition with loss rate, $D_{\mathrm{O}}\left(\mathrm{s}^{-1}\right)$. The dry deposition loss rate can be calculated from the dry deposition velocity, $\mathrm{v}_{\mathrm{dryO}}\left(\mathrm{m} \mathrm{s}^{-1}\right)$ and the depth of the atmospheric layer in contact with the ocean, $\mathrm{z}: \mathrm{D}_{\mathrm{O}}=\mathrm{v}_{\mathrm{dryO}} / \mathrm{z}$. The change of the concentration of organic bromine can therefore be written as in equation (2).

$$
\frac{d c_{O}}{d t}=\frac{F_{O}}{z}-D_{O} c_{O}-k_{O} c_{O}=\frac{F_{O}}{z}-\frac{v_{d r y} O}{z} c_{O}-k_{O} c_{O}
$$

Photochemical breakdown of organic bromine leads to the formation of inorganic bromine with concentration $c_{I}\left(\mathrm{~mol} \mathrm{~m}^{-3}\right)$. Here we use the term "inorganic bromine" for all inorganic gaseous bromine compounds as inorganic bromine cycles very rapidly between different species (such as $\mathrm{Br}, \mathrm{BrO}, \mathrm{HOBr}, \mathrm{Br}_{2}, \mathrm{BrCl}$ ) due to fast gas phase and heterogeneous reactions. Heterogeneous reactions lead to a rapid re-release of particulate bromine to the gas phase of bromine [von Glasow and Crutzen, 2007]. Loss of atmospheric inorganic bromine is due to dry deposition of gaseous inorganic bromine and dry and wet deposition of particulate inorganic bromine with a first order loss rate, $\mathrm{k}_{\mathrm{I}}\left(\mathrm{s}^{-1}\right)$. The 
conversion of organic bromine to inorganic bromine, $C_{O \rightarrow I}$, acts as a source for inorganic bromine as does a source flux of inorganic bromine, $\mathrm{F}_{\mathrm{I}}$ (equation (3)).

$$
\frac{d c_{I}}{d t}=\frac{F_{I}}{z}+C_{O \rightarrow I}-k_{I} c_{I}
$$

where $C_{O \rightarrow I}$ can be identified as in equation (4).

$$
C_{O \rightarrow I}=k_{O} c_{O}
$$

where $\varepsilon$ is the conversion efficiency. Note that the conversion efficiency does not have to be applied in equation (2) as that deals with the loss of organic bromine. For a complete conversion of $\mathrm{CHBr}_{3}$ into inorganic bromine $\varepsilon=3$, as $\mathrm{CHBr}_{3}$ contains 3 bromine atoms. However, not all breakdown products of $\mathrm{CHBr}_{3}$ are likely producing inorganic bromine on timescales similar to the breakdown of $\mathrm{CHBr}_{3}$ so that this maximum value is unlikely to be reached (equation (5))

$$
\frac{d c_{I}}{d t}=\frac{F_{I}}{z}+\varepsilon k_{O} c_{O}-k_{I} c_{I}
$$

Assuming steady state $(\mathrm{dc} / \mathrm{dt}=0)$, we can derive the expression given in equation (6) for the concentration of organic bromine $c_{\mathrm{O}}$ from equation (2):

$$
\begin{aligned}
& 0=\frac{F_{O}}{z}-\frac{v_{d r y} O}{z} c_{O}-k_{O} c_{O} \\
& c_{O}\left(\frac{v_{d r y}}{z}+k_{O}\right)=\frac{F_{O}}{z} \\
& c_{O}=\frac{F_{O}}{v_{d r y O}+z k_{O}}
\end{aligned}
$$

Assuming steady state for inorganic bromine as well and using expression (6) we get the following expression from equation (3):

$$
\begin{aligned}
& 0=\frac{F_{I}}{z}+\varepsilon k_{O} c_{O}-k_{I} c_{I} \\
& k_{I} c_{I}=\frac{F_{I}}{z}+\varepsilon k_{O} c_{O} \\
& c_{I}=\frac{F_{I}}{z k_{I}}+\varepsilon \frac{k_{O}}{k_{I}} c_{O} \\
& c_{I}=\frac{F_{I}}{z k_{I}}+\varepsilon \frac{k_{O}}{k_{I}} \frac{F_{O}}{v_{d r y}+z k_{O}}
\end{aligned}
$$

Using equation (7) we can estimate the inorganic bromine concentrations. We have to make assumptions about the flux of inorganic bromine, $F_{\text {inorg }}$, the mixed layer height, $\mathrm{z}$, the dry deposition velocity for organic bromine, $\mathrm{v}_{\mathrm{dry}}, \mathrm{O}$, and the first order loss rates, $\mathrm{k}_{\mathrm{O}}$ and $\mathrm{k}_{\mathrm{I}}$. It has been estimated that a source strength of inorganic bromine of $17 \mathrm{ppt} \mathrm{d}^{-1}$ would be required in order to reproduce so-called ozone depletion events (ODE) [Sander et al., 1997], which we applied as well as a tenth of that for non-ODE conditions. We varied the mixed layer height, $\mathrm{z}$, between $100 \mathrm{~m}$ and $500 \mathrm{~m}$, used model estimates for the dry deposition velocity for $\mathrm{CHBr}_{3}$ of $\mathrm{v}_{\mathrm{dry}, \mathrm{O}}=6.4 \times 10^{-4} \mathrm{~m} \mathrm{~s}^{-1}$ and used a first order loss rate for inorganic bromine of $\mathrm{k}_{\mathrm{I}}=2.31 \times 10^{-6} \mathrm{~s}^{-1}$ which corresponds to a lifetime of inorganic bromine of $\tau_{\mathrm{I}}=5 \mathrm{~d}$ [von Glasow et al., 2004]. We used a first order loss rate for organic bromine of $\mathrm{k}_{\mathrm{O}}=8.27 \times 10^{-7} \mathrm{~s}^{-1}$. This corresponds

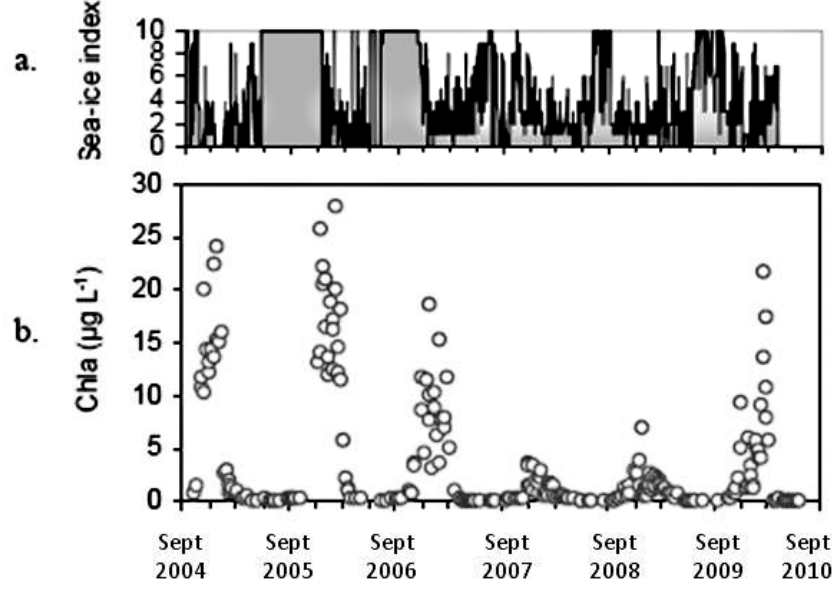

Figure 2. Temporal variability in (a) the sea-ice index and (b) total chlorophyll $a$ at $15 \mathrm{~m}$ depth at the RaTS site between 2005 and 2010. In Figure 2a an ice-index score of 10 is recorded during periods of fast-ice cover and 0 when there is open water.

to a $\mathrm{CHBr}_{3}$ lifetime $\left(\tau_{\mathrm{O}}\right)$ of $=14 \mathrm{~d}$ which is consistent with that calculated in Moortgat et al. [1993].

\section{Results and Discussion}

\subsection{Oceanographic and Biological Parameters}

[10] An analysis of long-term data collected at the RaTS site [Clarke et al., 2008] shows that between 1998 and 2006 the annual cycle of chlorophyll $a$ shows the typical high latitude pattern of a well-defined summer phytoplankton bloom following sea-ice retreat combined with a long winter period of very low chlorophyll levels under the ice. However, recent measurements show that significant changes have occurred in the sea ice-ocean system at the RaTS site since 2007. Specifically, winter sea-ice duration has decreased from $>150$ to $<50$ days (Figure 2a) due primarily to increased persistent northerly winds that drive the ice southward out of northern Marguerite Bay as it forms [Meredith et al., 2010]. These persistent northerlies and absence of sea-ice cover have resulted in deep upper ocean mixed layers in winter that persisted through to the start of the summer seasons of 2008/2009 and 2009/2010 (Figure 3). Later in the summers of these years, the mixed-layers shallowed to more normal levels due to freshwater input, mainly from melting glacial ice [Meredith et al., 2010], with intermittent periods of deep mixing.

[11] Chlorophyll $a$ concentrations measured during summers that followed winter periods with reduced fast-ice duration were generally lower and more variable (Figure $2 b$ ). Concentrations $\geq 5 \mu \mathrm{g}(\operatorname{chl} a) \mathrm{L}^{-1}$ indicating bloom conditions [Montes-Hugo et al., 2009] were only measured during 3 and $25 \%$ of the sampling events during the summer periods of 2008/2009 and 2009/2010, respectively. This is in contrast to $78 \%$ for the summer of $2005 / 2006$ and $56 \%$ for April to October 2006/2007. Analysis of size-fractionated chlorophyll $a$ data for the RaTS site reveals that there is a hyperbolic relationship between total chlorophyll $a$ and the percentage of the total that is derived from cells in the $\geq 20 \mu \mathrm{m}$ size fraction (Figure 4). The resulting relationship 

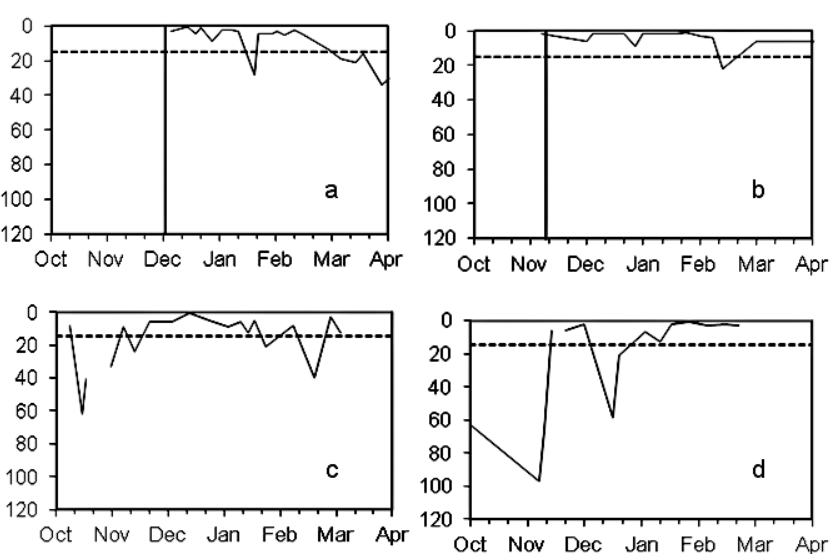

Figure 3. Variability in mixed-layer depths at the Rothera Time series (RaTS) site during the summer periods (October to April) of (a) 2005/2006, (b) 2006/2007, (c) 2008/2009 and (d) 2009/2010 (thin black lines). The bold horizontal dashed line in all plots shows the $15 \mathrm{~m}$ sample depth and the bold black vertical lines show the timing of sea-ice retreat.

is typical for Southern Ocean Waters and suggests that above a concentration of $5 \mu \mathrm{g} \mathrm{L}^{-1}, \geq 75 \%$ of the chlorophyll $a$ is derived from the largest phytoplankton size class. As diatoms are known to dominate $\geq 20 \mu \mathrm{m}$ phytoplankton biomass along the WAP [Garibotti et al., 2003; Annett et al., 2010] these results confirm that summer periods preceded by a short duration of winter fast-ice at the RaTS site are characterized by reduced diatom bloom occurrence. This is consistent with recent observations in the northern sector of the WAP [Montes-Hugo et al., 2009].

\subsection{Seawater Bromocarbon Concentrations}

[12] Alongside changes in the phytoplankton community a distinct alteration in seawater bromocarbon cycling was observed at the RaTS site during summer periods (October to April) that followed winters with a relatively short ( $<50$ days) fast-ice duration (Figure 5). From 2007 the seawater concentrations of $\mathrm{CHBr}_{3}$ were generally lower than 100 pmol $\mathrm{L}^{-1}$ which is in contrast to the peaks of $>250 \mathrm{pmol} \mathrm{L}^{-1}$ measured during previous years (Figure 5a) [Hughes et al., 2009]. The only occasion since 2007 when $\mathrm{CHBr}_{3}$ concentrations increased above $100 \mathrm{pmol} \mathrm{L}^{-1}$ was during the late summer diatom bloom that occurred in 2010 when an increase up to $580( \pm 80.8) \mathrm{pmol} \mathrm{L}^{-1}$ was measured. It is interesting that $\mathrm{CH}_{2} \mathrm{Br}_{2}$ does not appear to be subject to the same change between long and short fast-ice seasons, with relatively similar maximum concentrations (20-40 pmol $\mathrm{L}^{-1}$ ) measured during all summer periods (Figure $5 \mathrm{~b}$ ). When the data are grouped seawater $\mathrm{CHBr}_{3}$ concentrations were found to be significantly higher during diatom bloom conditions ( $\geq 5 \mu \mathrm{g}$ chlorophyll $a \mathrm{~L}^{-1} ; \mathrm{P}<0.001$, Mann-Whitney; Figure $5 \mathrm{c}$ ) with an average concentration (and range) of 122 (14.7-580) pmol L ${ }^{-1}$ compared to 42.9 (12.0-126) pmol $\mathrm{L}^{-1}$ for non-bloom conditions. $\mathrm{CH}_{2} \mathrm{Br}_{2}$ concentrations in the two groups were not statistically different $(\mathrm{P}=0.3$, MannWhitney) with averages of $10.6(1.8-32.2)$ and $10.8(0.6-$ 32.4) pmol $\mathrm{L}^{-1}$ for diatom bloom and non-bloom waters, respectively (Figure 5d).
[13] The significantly higher $\mathrm{CHBr}_{3}$ concentrations measured during bloom conditions at the RaTS site can be explained by a diatom source [Moore et al., 1996]. Other potential controls on $\mathrm{CHBr}_{3}$ concentrations that could have also led to bloom conditions, such as reduced mixing and sea-ice brine release, are unlikely to have played a significant role in controlling the observed variability. For example, aside from at the start of the summer periods of 2008/2009 and 2009/2010 when the absence of fast-ice cover meant greater exposure to wind-induced mixing, there were still long periods of shallow stratification $(<15 \mathrm{~m})$ later in the summer (Figure 3) during which $\mathrm{CHBr}_{3}$ concentrations remained low. Also the observed pattern of increase in $\mathrm{CHBr}_{3}$ concentrations does not suggest that release from seaice brine is a significant source of this compound to the upper water column as has been found for other biogenic trace gases (e.g., DMS) [Delille et al., 2007]. Brine release will occur simultaneously with ice break-up but, following a winter period with long winter sea-ice duration at the RaTS site, $\mathrm{CHBr}_{3}$ concentrations took $>20$ days to reach maximum levels after retreat.

[14] The simultaneous formation of $\mathrm{CHBr}_{3}$ and $\mathrm{CH}_{2} \mathrm{Br}_{2}$ has been observed in laboratory cultures of polar diatoms [Moore et al., 1996] so a similar response to the change in the phytoplankton community would have been expected. One explanation for the different response could be bacterial breakdown. Previous work carried out in temperate ocean waters has shown that $\mathrm{CH}_{2} \mathrm{Br}_{2}$ is broken down by bacteria but $\mathrm{CHBr}_{3}$ was not found to be subject to this loss process [Goodwin et al., 1997]. If these results are representative of processes occurring in the Southern Ocean, differences in bacterial activity in diatom bloom and non-bloom waters could provide an explanation for the disparity in response to the change in phytoplankton community structure at the

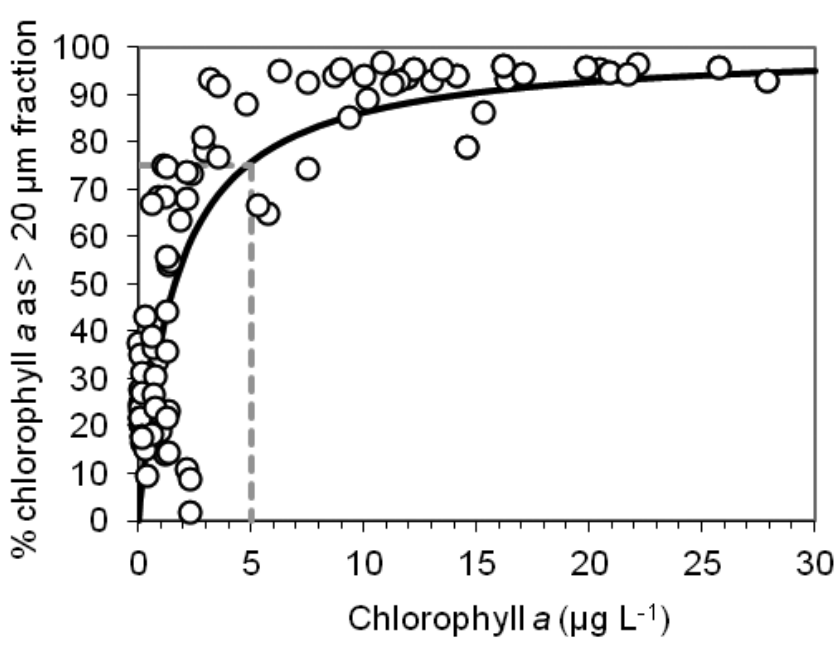

Figure 4. Relationship between total chlorophyll $a$ concentrations and the $\%$ contribution from the $>20 \mu \mathrm{m}$ size-fraction at the Rothera Time series (RaTS) site. The solid line is the best fit hyperbolic of the form $y=a x /(b+x)$ where $a=100$ and $b=1.6\left(R^{2}=0.76, n=100\right.$, slope $\left.=0.9\right)$. The gray dashed lines highlight how above $5 \mu \mathrm{g} \mathrm{L}^{-1}$ total chlorophyll $a$ is dominated by the $>20 \mu \mathrm{m}$ fraction. 

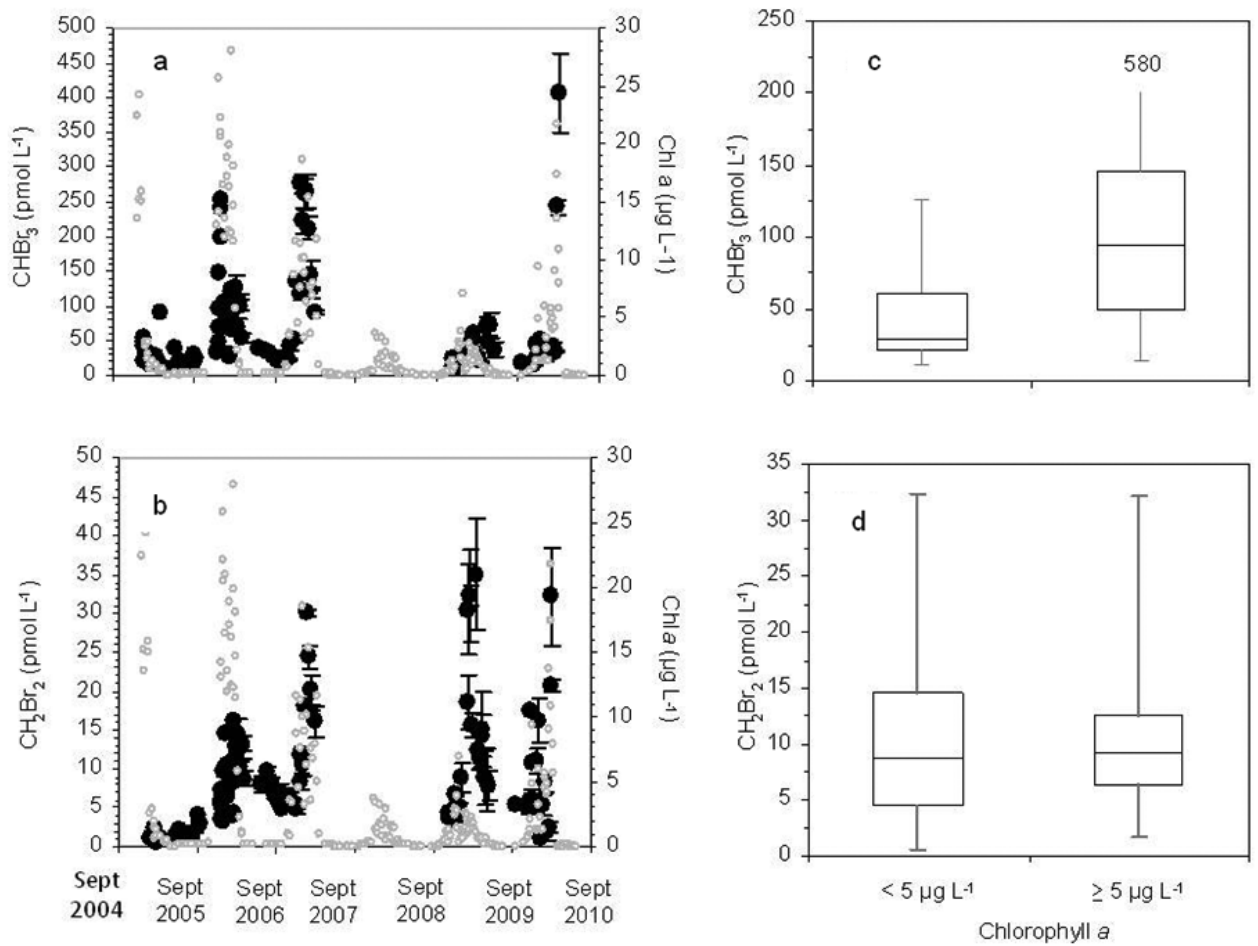

Figure 5. Inter-annual variability in seawater (a) $\mathrm{CHBr}_{3}$ and (b) $\mathrm{CH}_{2} \mathrm{Br}_{2}$ concentrations at $15 \mathrm{~m}$ at the Rothera Time series (RaTS) site (black dots). The chlorophyll $a$ concentrations are shown as gray circles for comparison. Error bars on the bromocarbon data show the range of at least duplicate analyses. The box and whisker plots show the range of (c) seawater $\mathrm{CHBr}_{3}$ and (d) seawater $\mathrm{CH}_{2} \mathrm{Br}_{2}$ concentrations measured at the RaTS site $(15 \mathrm{~m})$ when total chlorophyll $a$ concentrations were $<5$ and $\geq 5 \mu \mathrm{g} \mathrm{L}^{-1}$. The information shown in Figures $5 \mathrm{c}$ and $5 \mathrm{~d}$ includes the 25 th percentile, median and 75 th percentile and the error bars show the maximum and minimum concentrations in each group.

RaTS site. For example, factors such as a reduction in the availability of diatom-derived organic material and higher UV exposure due to reduced attenuation in non-bloom waters could have impacted bacterial community composition, biomass and activity in recent years [Kjelleberg et al., 1987; Castro, 2003]. These changes could have led to a reduction in the rate of $\mathrm{CH}_{2} \mathrm{Br}_{2}$ breakdown and allowed the concentrations of this compound to increase relative to $\mathrm{CHBr}_{3}$ during the 2008-2010 summers. While this appears to be a plausible explanation it is currently speculation and more detailed process information specific to the study site is obviously required to determine the exact cause of the observed disparity in response.

\subsection{Sea-to-Air Flux Rates}

[15] The reduction in seawater $\mathrm{CHBr}_{3}$ concentrations following a switch from diatom bloom to non-bloom conditions will drive a change in the disequilibrium $(\Delta \mathrm{C})$ between the surface ocean and the atmosphere, and this is the thermodynamic determinant of the flux rate $(\mathrm{F})$ across the sea surface (equation (1)) [Liss and Slater, 1974]. So far our discussion has focused on bromocarbon concentrations measured at $15 \mathrm{~m}$ as size-fractionated chlorophyll $a$ data has been collected at the site regularly since 1997 , but surface concentrations are of primary interest when calculating fluxes. The absence of detailed biological data does not permit the same groupings based on community size-structure and statistical analyses to be done for surface data. However, highly significant correlations were found between $\mathrm{CHBr}_{3}$ concentrations measured in the surface waters and at $15 \mathrm{~m}$ $\left(\mathrm{CHBr}_{3}, \mathrm{R}^{2}=0.92, \mathrm{p}<0.001, \mathrm{n}=40\right.$, slope $\left.=1.0\right)$ and in situ chlorophyll $a$ fluorescence data suggests that inter-annual variability in microalgal biomass was similar at the two depths. While bromocarbon sub-surface maxima have been reported previously for the RaTS site [Hughes et al., 2009] this was only seen on a couple of occasions and so appears to be a very transient feature. Together this confirms that the conclusions drawn for $15 \mathrm{~m}$ can be extrapolated to surface waters.

[16] Mean sea-to-air $\mathrm{CHBr}_{3}$ flux rates calculated as described in section 2.3 from spot seawater and air data are 107 ( -13 to 353$) \mathrm{nmol} \mathrm{m}^{-2} \mathrm{~d}^{-1}$ for diatom bloom conditions and 34 (-49 to 227) nmol $\mathrm{m}^{-2} \mathrm{~d}^{-1}$ for non-bloom periods. Clearly the results of these calculations suggest that on average higher $\mathrm{CHBr}_{3}$ emission rates are encountered during diatom bloom conditions. A number of variables in addition to the seawater concentration control trace gas flux rates from seawater including the $\mathrm{CHBr}_{3}$ atmospheric mixing ratio which was found to range from 0.3 to $15.3 \mathrm{ppt}$ during the study period, seawater temperature $\left(-1.7\right.$ to $\left.2.3^{\circ} \mathrm{C}\right)$ and wind speed ( 0.1 to $28 \mathrm{~m} \mathrm{~s}^{-1}$, see Table 1$)$. No significant difference in these variables was observed between diatom bloom and non-bloom conditions so the change in $\mathrm{CHBr}_{3}$ flux is likely to be mainly driven by variability in seawater concentrations. However, it is important to explore the potential for biases associated with our sampling regime by examining 
Table 1. Information on the Data Sets Used to Calculate Probability Density Distributions of $\mathrm{CHBr}_{3}$ Sea-to-Air Flux Rates From Non-bloom and Diatom Bloom Waters Where Chlorophyll $a$ Concentrations Were $<5$ and $\geq 5 \mu \mathrm{g} \mathrm{L}^{-1}$, Respectively

\begin{tabular}{llll}
\hline \multicolumn{1}{c}{ Variable } & \multicolumn{1}{c}{ Units } & \multicolumn{1}{c}{ Range } & Mean \\
\hline $\mathrm{CHBr}_{3}\left(<5 \mu \mathrm{g} \mathrm{L}^{-1}\right)$ & $\mathrm{pmol} \mathrm{L}^{-1}$ & 12.0 to 126 & 42.9 \\
$\mathrm{CHBr}_{3}\left(\geq 5 \mu \mathrm{g} \mathrm{L}^{-1}\right)$ & $\mathrm{pmol} \mathrm{L}$ & 14.7 to 580 & 122 \\
$\mathrm{CHBr}_{3}($ air $)$ & $\mathrm{ppt}$ & 0.3 to 15.3 & 2.7 \\
Wind speed $^{\mathrm{a}}$ & $\mathrm{m} \mathrm{s}^{-1}$ & 0.1 to 28 & 5.6 \\
Seawater temperature $^{\mathrm{b}}$ & ${ }^{\circ} \mathrm{C}$ & -1.7 to 2.3 & 0.1 \\
Seawater salinity & & 32.8 to 34.0 & 33.4 \\
\hline
\end{tabular}

${ }^{\mathrm{a}}$ Data set made up of all summer season (October to April) wind speeds recorded for the period 2005-2010.

${ }^{\mathrm{b}}$ Data sets made up of surface seawater salinities and temperatures recorded during the summer season (October to April) CTD events.

how flux rates vary across a realistic range of these other controlling variables [Johnson et al., 2011]. This is especially important as analysis of the data suggests that the various controls on the $\mathrm{CHBr}_{3}$ flux rate are decoupled $\left(\mathrm{R}^{2}<0.1\right)$ and that coincidence of extreme values during sampling is purely by chance.

[17] A probabilistic approach was used to provide a more robust examination of the likely change in emission rates in response to a reduction in diatom dominance than is possible using the average of spot flux calculations. This involved producing density distributions of likely $\mathrm{CHBr}_{3}$ flux rates given a wide range of possible combinations of the controlling variables (see Table 1) using a Monte Carlo-type statistical analysis. To ensure good coverage of parameter space a latin hypercube technique [Iman et al., 1981] was employed to sample 10,000 combinations of controlling variables and these were used to produce the flux distributions. This technique predicts mean $\mathrm{CHBr}_{3}$ emission rates of 117 and $29 \mathrm{nmol} \mathrm{m}^{-2} \mathrm{~d}^{-1}$ for diatom bloom and non-bloom waters, respectively. These average flux rates are similar to those calculated from spot measurements suggesting that the sampling regime was sufficient to cover parameter space and the values obtained indicate that summer sea-to-air $\mathrm{CHBr}_{3}$ emission rates from coastal waters of the WAP are reduced by a factor of 3-4 following the switch toward reduced diatom dominance.

\subsection{Atmospheric Chemistry}

[18] The breakdown of oceanic $\mathrm{CHBr}_{3}$ upon emission to the atmosphere will serve as a source of inorganic bromine to the Antarctic boundary layer alongside emissions from first year sea-ice [Simpson et al., 2007] and release from sea salt aerosols [Vogt et al., 1996]. This reactive bromine is involved in ozone depletion and large pulses in emissions are thought to be the major cause of the episodic ozone depletion events (ODEs) during which concentrations can decrease from background levels of around $30 \mathrm{ppb}$ to below analytical detection for 1-3 day periods during late winter/early spring in Antarctica (August to October) [Simpson et al., 2007; Jones et al., 2010]. Previous work suggests that abiotic sources dominate the supply of reactive bromine to the polar troposphere during ODEs with the contribution from organic bromine being negligible [Simpson et al., 2007]. An estimate of the bromine source strength required to support the total inorganic bromine levels measured in the troposphere during ODEs is $17 \mathrm{ppt}\left(\mathrm{Br}_{2}\right) \mathrm{d}^{-1}$ [Sander et al., 1997]. The organic bromine fluxes we report are averages for the 7 month period between October to April which is outside of ODEs so it is of interest to explore the potential importance of a change in $\mathrm{CHBr}_{3}$ emission rates on inorganic bromine levels in the troposphere during this time. Understanding controls on tropospheric composition outside of ODEs is important as $\mathrm{BrO}$ has been measured in the Antarctic boundary layer yearround [Saiz-Lopez et al., 2007] and bromine-mediated oxidation is believed to dominate DMS breakdown throughout the austral summer (October to April) [Read et al., 2008].

[19] Budget calculations allowed us to estimate the total inorganic bromine levels that would result from the average $\mathrm{CHBr}_{3}$ flux rates we calculate for diatom bloom (i.e., $117 \mathrm{nmol} \mathrm{m}^{-2} \mathrm{~d}^{-1}$ ) and non-bloom conditions (i.e., $29 \mathrm{nmol} \mathrm{m} \mathrm{m}^{-2} \mathrm{~d}^{-1}$ ). These calculations (described in detail in section 2.4) assume that the $\mathrm{CHBr}_{3}$ emitted to the atmosphere is dispersed in the boundary layer of 100 to $500 \mathrm{~m}$ in height and is subject to both photochemical conversion to inorganic bromine and dry deposition. The inorganic bromine that is released from $\mathrm{CHBr}_{3}$, which includes a wide range of species $\left(\mathrm{Br}, \mathrm{BrO}, \mathrm{HOBr}, \mathrm{Br}_{2}, \mathrm{BrCl}\right.$ etc) that are cycled via fast gas phase and heterogeneous reactions, is lost from the atmosphere via dry deposition of gaseous forms and wet and dry deposition of particulate fractions with an estimated lifetime of $5 \mathrm{~d}$ [von Glasow et al., 2004].

[20] These calculations predict (steady state) total inorganic bromine mixing ratios of 6 to $9 \mathrm{ppt}$ for a $\mathrm{CHBr}_{3}$ emission rate of $29 \mathrm{nmol} \mathrm{m}^{-2} \mathrm{~d}^{-1}$ and 25 to $36 \mathrm{ppt}$ for $117 \mathrm{nmol} \mathrm{m} \mathrm{m}^{-2} \mathrm{~d}^{-1}$. The $\mathrm{Br}_{2}$ emission rate of $17 \mathrm{ppt} \mathrm{d}^{-1}$ estimated by Sander et al. [1997] for ODE conditions would give an inorganic bromine mixing ratio of $85 \mathrm{ppt}$ which is consistent with the model results presented in Piot and von Glasow [2008]. Hence, consistent with previous suggestions (reviewed by Simpson et al. [2007]), an additional $\mathrm{CHBr}_{3}$ flux at 29-117 $\mathrm{nmol} \mathrm{m}^{-2} \mathrm{~d}^{-1}$ would not have a major influence on the resulting inorganic bromine mixing ratios during ODE conditions. However, outside of ODEs the situation is likely very different.

[21] The source of inorganic bromine outside of ODE conditions is ill-constrained, especially in the Antarctic. Based on studies in the marine boundary layer [e.g., von Glasow et al., 2002] we estimate the abiotic source of inorganic bromine from sea salt aerosol outside of ODEs to be $10 \%$ of the source from first-year sea ice. Under these conditions, our calculations suggest that $\mathrm{CHBr}_{3}$ emissions will be the dominant source of tropospheric inorganic bromine. We estimate that a $\mathrm{Br}_{2}$ emission rate of $1.7 \mathrm{ppt} \mathrm{d}^{-1}$ will yield an inorganic mixing ratio of $9 \mathrm{ppt}$. Therefore the total mixing ratio that would result from the simultaneous emission of $\mathrm{Br}_{2}$ and $\mathrm{CHBr}_{3}$ is $15-18 \mathrm{ppt}$ at $29 \mathrm{nmol}\left(\mathrm{CHBr}_{3}\right) \mathrm{m}^{-2} \mathrm{~d}^{-1}$ and 34-45 ppt at $117 \mathrm{nmol} \mathrm{m}^{-2} \mathrm{~d}^{-1}$; suggesting that $\mathrm{CHBr}_{3}$ contributes 40 to $51 \%$ of total tropospheric inorganic bromine during non-bloom conditions and 74 to $81 \%$ during bloom periods. Under conditions with low wind speeds and therefore smaller sea salt fluxes, direct release of inorganic bromine is likely less than our estimate and the relative importance of organic bromine emissions would be even higher. Overall the results of these calculations suggest that total inorganic bromine levels in the troposphere could be reduced by a factor of $2-3$ from 34 to $45 \mathrm{ppt}$ to $15-18 \mathrm{ppt}$ and the importance of $\mathrm{CHBr}_{3}$ as a source diminished by $30-34 \%$ 
following a switch toward a phytoplankton population with reduced diatom biomass on the western Antarctic Peninsula.

\section{Summary and Conclusions}

[22] This work has captured a biogeochemical response to a climate-induced decrease in diatom dominance in coastal waters of the WAP that will lead to a change in the supply of $\mathrm{CHBr}_{3}$ from the oceans to the troposphere. Our calculations suggest that this will feedback on atmospheric composition and chemistry through decreasing inorganic bromine concentrations. This study has focused on the WAP, which is one of the most rapidly changing marine environments in the world, and which serves as a bell-weather for other ocean regions. As climate change progresses wide-spread shifts in diatom biomass are expected to occur throughout the world's oceans in response to climate-induced changes in nutrients, light and temperature [Marinov et al., 2010] and these could also lead to altered bromocarbon emissions from the oceans to the atmosphere. Given the wide range of biogenic trace gases that are produced in the oceans [Liss, 2007] there are likely to be many more biogeochemical responses to climateinduced changes in marine ecosystems. A major future research priority must be to quantify the main biogeochemical responses to climatic forcing and bring them together in Earth system models to assess the potential net magnitude and sign of any climate-marine biosphere feedbacks.

[23] Acknowledgments. This work was funded by a UK Natural Environmental Research Council (NERC) Antarctic Funding Initiative (AFI) project NE/E013287/1. The authors acknowledge the help and support of British Antarctic Survey personnel in Cambridge and those based at the Rothera Research Station during our sampling periods (2005-2010). We also thank Martin Miller and Kathy Salisbury in the AFI office for their assistance in planning the project and field campaigns. We also acknowledge the helpful comments from the anonymous reviewer.

\section{References}

Annett, A. L., D. S. Carson, X. Crosta, A. Clarke, and R. S. Ganeshram (2010), Seasonal progression of diatom assemblages in surface waters of Ryder Bay, Polar Res., 33, 13-29.

Castro, C. E. (2003), The natural destruction of organohalogen compounds, Environmental dehalogenation, in The Handbook of Environmental Chemistry, vol. 3P, pp. 235-264, Springer, Berlin, doi:10.1007/b10455.

Clarke, A., M. P. Meredith, M. I. Wallace, M. A. Brandon, and D. N. Thomas (2008), Seasonal and inter-annual variability in temperature, chlorophyll and macronutrients in northern Marguerite Bay, Antarctica, Deep Sea Res., Part II, 55, 1988-2006, doi:10.1016/j.dsr2.2008.04.035.

Delille, B., B. Jourdain, A. V. Borges, J.-L. Tison, and B. Delille (2007), Biogas $\left(\mathrm{CO}_{2}, \mathrm{O}_{2}\right.$, dimethylsulphide) dynamics in spring Antarctic fast ice, Limnol. Oceanogr., 52(4), 1367-1379, doi:10.4319/lo.2007.52.4. 1367.

Denman, K. L., et al. (2007), Couplings between changes in the climate system and biogeochemistry, in Climate Change 2007: The Physical Science Basis. Contribution of Working Group I to the Fourth Assessment Report of the Intergovernmental Panel on Climate Change, edited by S. Solomon et al., pp. 500-584, Cambridge Univ. Press, Cambridge, U. K.

Duce, R. A., et al. (1991), The atmospheric input of trace species to the world ocean, Global Biogeochem. Cycles, 5, 193-259, doi:10.1029/ 91GB01778.

Garibotti, I. A., M. Vernet, M. E. Ferrario, R. C. Smith, R. M. Ross, and L. B. Quetin (2003), Phytoplankton spatial distribution patterns along the western Antarctic Peninsula (Southern Ocean), Mar. Ecol. Prog. Ser., 261, 21-39, doi:10.3354/meps261021.

Goodwin, K. D., M. E. Lindstrom, and R. S. Oremland (1997), Marine bacterial degradation of brominated methanes, Environ. Sci. Technol., 31, 3188-3192, doi:10.1021/es970165g.

Gruber, N. (2011), Warming up, turning sour, losing breath: Ocean biogeochemistry under global change, Philos. Trans. R. Soc. A, 369 1980-1996, doi:10.1098/rsta.2011.0003.
Hoegh-Guldberg, O., and J. F. Bruno (2010), The impact of climate change on the World's marine ecosystems, Science, 328, 1523-1528, doi:10.1126/science. 1189930

Hughes, C., A. L. Chuck, H. Rossetti, P. J. Mann, S. M. Turner, A. Clarke, R. Chance, and P. Liss (2009), Seasonal cycle of seawater bromoform and dibromomethane concentrations in a coastal bay on the western Antarctic Peninsula, Global Biogeochem. Cycles, 23, GB2024, doi:10.1029/ 2008GB003268

Iman, R. L., J. C. Helton, and J. E. Campbell (1981), An approach to sensitivity analysis of computer models, part 1 . Introduction, input variable selection and preliminary variable assessment, J. Qual. Technol., 13, 174-183.

Johnson, M. T. (2010), A numerical scheme to calculate temperature and salinity-dependent air-water transfer velocities for any gas, Ocean Sci. Discuss., 7, 251-290, doi:10.5194/osd-7-251-2010.

Johnson, M. T., C. Hughes, T. G. Bell, and P. S. Liss (2011) A Rumsfeldian analysis of uncertainty in air-sea gas exchange, in Gas Transfer at Water Surfaces 2011, edited by S. Komori, W. McGillis, and R. Kurose, pp. 464-484, Kyoto Univ. Press, Kyoto, Japan.

Jones, A. E., P. S. Andersen, E. Wolff, H. K. Roscoe, G. J. Marshall, A. Richter, N. Brough, and S. R. Colwell (2010), Vertical structure of Antarctic tropospheric ozone depletion events: Characteristics and broader implications, Atmos. Chem. Phys., 10, 7775-7794, doi:10.5194/ acp-10-7775-2010.

Kjelleberg, S., M. Hermansson, and P. Marden (1987), The transient phase between growth and non-growth in heterotrophic bacteria, with emphasis on the marine environment, Annu. Rev. Microbiol., 41, 25-49, doi:10.1146/annurev.mi.41.100187.000325

Liss, P. S. (2007), Trace gas emissions from the marine biosphere, Philos. Trans. R. Soc. A, 365, 1697-1704

Liss, P. S., and P. G. Slater (1974), Flux of gases across the air-sea interface, Nature, 247, 181-184, doi:10.1038/247181a0.

Marinov, I., S. C. Doney, and I. D. Lima (2010), Response of ocean phytoplankton community structure to climate change over the 21 st century: Partitioning the effects of nutrients, temperature and light, Biogeosciences, 7, 3941-3959, doi:10.5194/bg-7-3941-2010.

Meredith, M. P., and J. C. King (2005), Rapid climate change in the ocean west of the Antarctic Peninsula during the second half of the 20th century, Geophys. Res. Lett., 32, L19604, doi:10.1029/2005GL024042.

Meredith, M. P., M. I. Wallace, S. E. Stammerjohn, I. A. Renfrew, A. Clarke, H. J. Venables, D. R. Shoosmith, T. Souster, and M. J. Leng (2010), Changes in the freshwater composition of the upper ocean west of the Antarctic Peninsula during the first decade of the 21st century, Prog. Oceanogr., 87, 127-143, doi:10.1016/j.pocean.2010.09.019.

Montes-Hugo, M., S. C. Doney, H. W. Ducklow, W. Fraser, D. Martinson, S. E. Stammerjohn, and O. Schofield (2009), Recent changes in phytoplankton communities associated with rapid regional climate change along the western Antarctic peninsula, Science, 323, 1470-1473, doi:10.1126/science. 1164533 .

Moore, R. M., M. Webb, R. Tocarkzyk, and R. Wever (1996), Bromoperoxidase and iodoperoxidase enzymes and production of halogenated methanes in marine diatom cultures, J. Geophys. Res., 101, 20,899-20,908, doi:10.1029/96JC01248

Moortgat, G. K., R. Meller, and W. Schneider (1993), Temperature dependence $(256-296 \mathrm{~K})$ of the absorption cross sections of bromoform in the wavelength range $285-360 \mathrm{~nm}$, in Tropospheric Chemistry of Ozone in Polar Regions, NATO ASI Ser., Ser. 1: Global Environ. Change, vol. 7 , edited by H. Niki and K. H. Becker, pp. 359-370, Springer, New York.

Nightingale, P. D., G. Malin, C. S. Law, A. J. Watson, P. S. Liss, M. I. Liddicoat, J. Boutin, and R. C. Upstill-Goddard (2000), In situ evaluation of air-sea gas exchange parameterizations using novel conservative and volatile tracers, Global Biogeochem. Cycles, 14, 373-387, doi:10.1029/ 1999GB900091.

Piot, M., and R. von Glasow (2008), The potential importance of frost flowers, recycling on snow, and open leads for ozone depletion events, Atmos. Chem. Phys, 8, 2437-2467, doi:10.5194/acp-8-2437-2008.

Quack, B., and D. W. R. Wallace (2003), Air-sea flux of bromoform: Controls, rates and implications, Global Biogeochem. Cycles, 17(1), 1023, doi:10.1029/2002GB001890.

Read, K. A., et al. (2008), DMS and MSA measurements in the Antarctic Boundary Layer: Impact of $\mathrm{BrO}$ on MSA production, Atmos. Chem. Phys. Discuss., 8, 2657-2694, doi:10.5194/acpd-8-2657-2008.

Reifenhäuser, W., and K. G. Heumann (1992), Bromo- and bromochloromethanes in the Antarctic atmosphere and the South Polar Sea, Chemosphere, 24, 1293-1300, doi:10.1016/0045-6535(92)90054-U.

Saiz-Lopez, A., A. S. Mahajan, R. A. Salmon, S. J.-B. Bauguitte, A. E. Jones, H. K. Roscoe, and J. M. C. Plane (2007), Boundary layer halogens in coastal Antarctica, Science, 317, 348-351, doi:10.1126/science. 1141408 . 
Salawitch, R. J. (2006), Biogenic bromine, Nature, 439, 275-277, doi:10.1038/439275a.

Sander, R., R. Vogt, G. W. Harris, and P. J. Crutzen (1997), Modeling the chemistry of ozone, halogen compounds, and hydrocarbons in the Arctic troposphere during spring, Tellus, Ser. B, 49, 522-532.

Simpson, W. R., et al. (2007), Halogens and their role in polar boundarylayer ozone depletion, Atmos. Chem. Phys., 7, 4375-4418, doi:10.5194/ acp-7-4375-2007.

Stammerjohn, S. E., D. G. Martinson, R. C. Smith, and R. A. Ianuzzi (2008), Sea ice in the western Antarctic peninsula region: Spatio-temporal variability from ecological and climate change perspectives, Deep Sea Res., Part II, 55, 2041-2058, doi:10.1016/j.dsr2.2008.04.026.

Sturges, W. T., G. F. Cota, and P. T. Buckley (1992), Bromoform emission from ice algae, Nature, 358, 660-662, doi:10.1038/358660a0.

Vaughan, D. G., G. J. Marshall, W. M. Connelly, C. Parkinson, R. Mulvaney, D. A. Hodgson, J. C. King, C. J. Pudsey, and J. Turner (2003), Recent rapid regional climate warming on the Antarctic peninsula, Clim. Change, 60 , 243-274, doi:10.1023/A:1026021217991.
Vogt, R., P. J. Crutzen, and R. Sander (1996), A mechanism for halogen release from sea-salt in the remote marine boundary layer, Nature, 383 327-330, doi:10.1038/383327a0.

von Glasow, R, and P. J. Crutzen (2004), Model study of multiphase DMS oxidation with a focus on halogens, Atmos. Chem. Phys., 4, 589-608, doi:10.5194/acp-4-589-2004.

von Glasow, R., and P. J. Crutzen (2007), Tropospheric halogen chemistry, in Treatise on Geochemistry, vol. 4, The Atmosphere, 2nd ed., edited by H. D. Holland and K. K. Turekian, pp. 1-67, Elsevier, Amsterdam.

von Glasow, R., R. Sander, A. Bott, and P. J. Crutzen (2002), Modeling halogen chemistry in the marine boundary layer: 1. Cloud-free MBL, J. Geophys. Res., 107(D17), 4341, doi:10.1029/2001JD000942.

von Glasow, R., R. von Kuhlmann, M. G. Lawrence, U. Platt, and P. J. Crutzen (2004), Impact of reactive bromine chemistry in the troposphere, Atmos. Chem. Phys., 4, 2481-2497, doi:10.5194/acp-4-2481-2004.

Yang, X., R. A. Cox, N. J. Warwick, J. A. Pyle, G. D. Carver, F. M. O'Connor, and N. H. Savage (2005), Tropospheric bromine chemistry and its impact on ozone: A model study, J. Geophys. Res., 110 , D23311, doi:10.1029/2005JD006244. 